\title{
Profound duodenogastric reflux causes pancreatic growth in rats
}

\author{
T Gasslander, H Mukaida, M K Herrington, R A Hinder, T E Adrian
}

\begin{abstract}
Although duodenogastric reflux is a physiological event, excessive reflux may be a pathogenetic factor in several diseases of the foregut, including cancer. Long term profound duodenogastric reflux produces pancreatic and gastric tumours in rats. The trophic effect of surgically induced duodenogastric reflux on the pancreas was investigated and the mechanisms involved were examined. Rats with profound reflux from a split gastroenterostomy were compared with sham operated and unoperated controls after two and six weeks. In the six week experiment, one reflux and one sham group were given the cholecystokinin (CCK) receptor antagonist devazepide (25 nmol/ $\mathrm{kg} / \mathrm{h})$. Duodenogastric reflux caused a significant increase in pancreatic weight, DNA, and plasma CCK and gastrin concentrations at both two and six weeks. Devazepide substantially reduced the pancreatic weight increase after six weeks but did not abolish it completely. CCK and gastrin were not affected by devazepide. These results suggest that CCK is largely responsible for the pancreatic growth induced by reflux but another factor may also be involved. The trophic effect of duodenogastric reflux may contribute to the increased incidence of pancreatic cancer reported after gastric surgery.
\end{abstract}

(Gut 1995; 36: 137-141)

Keywords: duodenogastric reflux, pancreatic growth.

The regulation of pancreatic growth and tumour development is not fully understood. Several peptide hormones, and cholecystokinin (CCK) in particular, are known, however, to be trophic to the pancreas in experimental animal models. ${ }^{12}$ The release of some of these growth factors is influenced by surgical manipulation of the gastrointestinal tract, such as bowel resection, cholecystectomy, and pancreatico-biliary diversion. ${ }^{3-9}$ Furthermore, some regulatory peptides stimulate the growth of pancreatic cancer in experimental animal models. ${ }^{10-15}$ Long term (56 weeks) duodenogastric reflux (DGR) in rats, induced by split gastrojejunostomy, has recently been shown to induce pancreatic hyperplasia and adenomatous nodules without using carcinogens. ${ }^{16}$ The underlying pathophysiological mechanism is not fully understood. In humans, several epidemiological studies have suggested that previous gastric surgery is a risk factor for pancreatic cancer. ${ }^{17-19}$ In the present study, the split gastrojejunostomy model was used to investigate the short term effects of pronounced duodenogastric reflux on pancreatic growth in the rat, and to evaluate the role of CCK in this process.

\section{Methods}

Male Wistar rats weighing 175-200 g (Sasco Inc, Omaha, Nebraska, USA), were used in the study. They were housed individually and fed standard pelleted rat chow with free access to water.

\section{DESIGN OF THE STUDY}

\section{Experiment I}

To investigate possible growth effects of duodenogastric reflux on the pancreas, a group of rats with a split gastrojejunostomy $(n=10)$ were compared with sham operated rats $(n=8)$ and unoperated controls $(n=8)$, two weeks after surgery.

\section{Experiment II}

The effects of duodenogastric reflux were studied six weeks after surgery. Seventeen animals had a split gastrojejunostomy performed and eight of these also received the specific CCK receptor antagonist devazepide (also called MK329, Merck Sharp \& Dohme). ${ }^{20}$ These were compared with sham operated rats with and without devazepide ( $\mathrm{n}=6$ and $\mathrm{n}=7$, respectively) and unoperated controls $(\mathrm{n}=5)$.

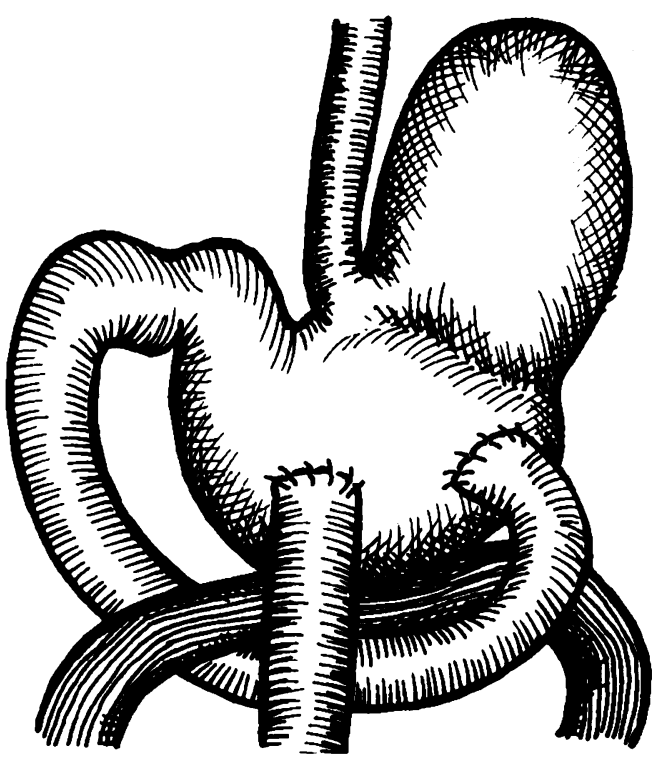

Figure 1: The split gastrojejunostomy. See Methods section for details of procedure. 
SURGICAL PROCEDURES

A split gastrojejunostomy (Fig 1) was performed through an upper midline incision under general anaesthesia (ketamine hydrochloride $100 \mathrm{mg} / \mathrm{ml}$ :xylazine $100 \mathrm{mg} / \mathrm{ml}$, $10: 1,0.1 \mathrm{ml} / 100 \mathrm{mg}$ body weight). The proximal jejunum was divided approximately $2 \mathrm{~cm}$ distal to the ligament of Treitz and the afferent loop was anastomosed to the greater curvature of the stomach $2-3 \mathrm{~mm}$ distal to the squamocolumnar junction using one layer of interrupted 7-0 Prolene sutures. The efferent jejunal loop was anastomosed to the stomach $10 \mathrm{~mm}$ distal to the afferent loop with the same technique. A sham operation was performed by transecting the proximal jejunum at the same point, anastomosing the bowel ends, and attaching the anastomosis to the stomach serosa. The surgery was performed after overnight fasting and the animals were deprived of water for 24 hours and of food for 48 hours after the procedure.

The CCK receptor antagonist devazepide was administered continuously $(25 \mathrm{nmol} / \mathrm{kg} / \mathrm{h}$ ) by means of a subcutaneously implanted osmotic mini pump (Alzet model no 2002, Alza, Palo Alto, CA). The devazepide was dissolved in $70 \%$ dimethyl sulphoxide and the mini pump was changed every 14 th day under ether inhalation anaesthesia. Animals without the antagonist, except for the unoperated controls, had a silicone tube (placebo) of the same dimensions as the minipump implanted and changed in the same manner. Previous experiments have shown no effect of infusion of the carrier vehicle on pancreatic growth. ${ }^{21}$

\section{TISSUE AND BLOOD COLLECTION}

After an overnight fast the animals were weighed, given an intraperitoneal injection of ${ }^{3} \mathrm{H}$-thymidine ([methyl- $\left.{ }^{3} \mathrm{H}\right]$ thymidine 25 $\mathrm{Ci} / \mathrm{mmol}$, Amersham Corp, Arlington, IL; $1 \mathrm{mCi} / \mathrm{kg}$ ), and killed one hour after the injection. They were anaesthetised in the same manner as for surgery (see above), the thorax was opened, and blood was collected from the right ventricle of the heart. The animals were thereby killed by exsanguination. The pancreas was excised; carefully dissected free from con-

2 weeks

A

Figure 2: Pancreatic wet weight/100 $\mathrm{g}$ body weight in rats two weeks $(A)$ and six weeks (B) after split gastrojejunostomy (DGR). Sham operation (Sham) implies small bowel transection.

Control = unoperated

controls. $M K=$ devazepide $25 \mathrm{nmol} / \mathrm{kg} / \mathrm{h} .{ }^{\star}=p<0.05$, $\star \star \star=p<0 \cdot 001$. nective tissue, fat, and lymph nodes; and weighed. It was minced with scissors and divided into aliquots for measurement of DNA, total protein, and ${ }^{3} \mathrm{H}$-thymidine uptake. The whole duodenum and the first $10 \mathrm{~cm}$ of the efferent loop of jejunum distal to the anastomosis were separately excised, measured, and weighed. The mucosa was scraped off, weighed, and divided into aliquots for measurement of DNA, total protein, ${ }^{3} \mathrm{H}$-thymidine uptake, and CCK. The aliquots of tissue were stored in $-80^{\circ} \mathrm{C}$ until analysis. The blood was immediately centrifuged at $4^{\circ} \mathrm{C}$ in tubes containing $2 \mathrm{mg}$ EDTA and $400 \mathrm{KIU}$ Aprotinin $/ \mathrm{ml}$ blood, and the plasma was stored at $-80^{\circ} \mathrm{C}$ for subsequent measurement of $\mathrm{CCK}$ and gastrin by radioimmunoassay.

\section{BIOCHEMICAL ASSAYS}

${ }^{3} \mathrm{H}$-thymidine uptake was determined in a beta counter after tissue solubilisation in TS-1 (Research Products Int Corp, Mount Prospect, IL) and the addition of a scintillation cocktail (Safety Solv, Research Products Int Corp). DNA was determined fluorimetrically on a crude tissue homogenate by the method described by Labarca and Paigen ${ }^{22}$ using bisbenzimidazole (Hoechst 33258) as reagent. Protein was determined spectrophotometrically by means of the Bio Rad Protein Assay (Bio-Rad Chemical Division, Richmond, CA).

\section{RADIOIMMUNOASSAY}

CCK and gastrin were extracted from plasma using reverse phase Sep-Pak C18 cartridges (Waters Associates, Milford, MA) as previously described. ${ }^{23} 24 \mathrm{CCK}$ was extracted from small bowel muscosa by boiling in $0.5 \mathrm{M}$ acetic acid for 10 minutes. The extracts were freeze dried and stored at $-20^{\circ} \mathrm{C}$. The peptides were later analysed by means of a specific, sensitive radioimmunoassay previously described in detail. ${ }^{2324}$ The CCK assay uses an antibody (CCK-2) raised to pure, unconjugated, porcine CCK-33 with Bolton and Hunter, reagent-labelled sulphated $\mathrm{CCK}-8$ as the tracer. Synthetic CCK-33 was used as a

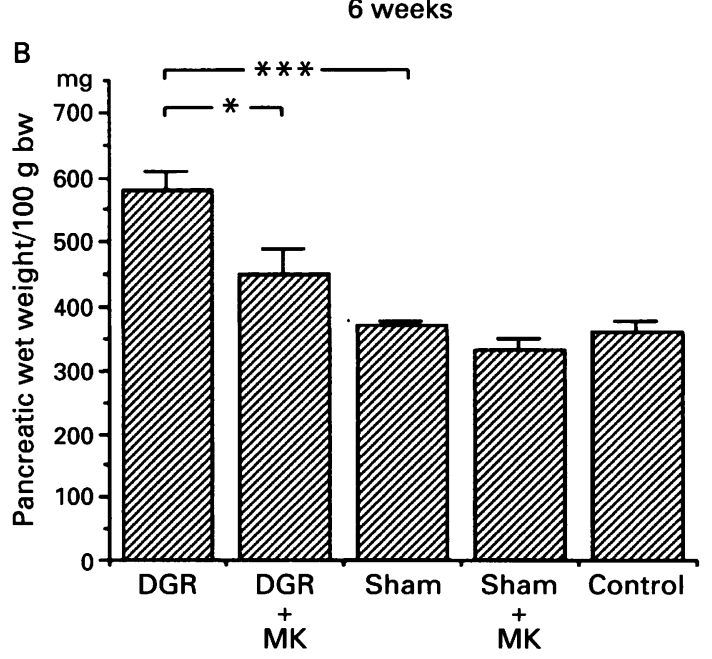


Total pancreatic DNA content ( $\mathrm{mg} / 100 \mathrm{~g}$ body weight, mean (SEM)) in rats two and six weeks after split gastrojejunostomy (DGR). Sham operation (Sham) implies small bowel transection. Control=unoperated controls. $M K=$ devazepide, $25 \mathrm{nmol} / \mathrm{kg} / \mathrm{h}$

\begin{tabular}{llllll}
\hline Time & $D G R$ & $D G R+M K$ & Sham & Sham $+M K$ & Control \\
\hline $2 \mathrm{wk}$ & $1.72(0.22)$ & & $1 \cdot 11(0.12)$ & & $1.26(0.14)$ \\
$6 \mathrm{wk}$ & $2.63(0.16)^{\star}$ & $2.09(0.17) \dagger$ & $1.82(0.13)$ & $1.73(0.20)$ \\
\hline
\end{tabular}

$\star=\mathrm{p}<0.05 v$ sham, $\mathrm{\dagger}=\mathrm{p}<0.05 v$ sham $+\mathrm{MK}$. sulphated CCK but shows no significant cross reaction with the gastrins.

\section{STATISTICAL ANALYSIS}

Statistical analysis was carried out using one way analysis of variance (ANOVA) with the Bonferroni post test for multiple comparisons.

\section{Results}

Overall mortality among all duodenogastric reflux rats was $13 \%$ (four of 31 ) with no deaths among the sham operated animals. There was no significant difference in postoperative weight change between any of the groups. No dilatation or other macroscopic change was found on the stomach or small bowel.

\section{TISSUE WET WEIGHTS} increased in the duodenogastric reflux animals after two weeks and was further increased after six weeks compared with sham (Fig 2).
The pancreatic wet weight was significantly

Devazepide reduced the pancreatic weight increase significantly $(\mathrm{p}<0.05)$ after six weeks in the duodenogastric reflux group to a level that was not significantly different from that of the sham operated rats (Fig 2). There was no difference in pancreatic wet weight between the sham operated animals and the unoperated controls at either two or six weeks. No significant difference was found in duodenal or jejunal mucosal weights between the duodenogastric reflux group and the sham or control groups at either time point (data not shown).

\section{PANCREATIC DNA AND PROTEIN CONTENT}

After six weeks, there was a significant increase in pancreatic DNA (mg/100 $\mathrm{g}$ body weight) in the duodenogastric reflux animals compared with the sham operated animals $(p<0.05)$ (Table). The difference in pancreatic DNA after two weeks did not reach statistical significance. The total pancreatic protein content was not significantly changed after either two or six weeks (data not shown).

\section{${ }^{3} \mathrm{H}$-THYMIDINE UPTAKE}

No difference in ${ }^{3} \mathrm{H}$-thymidine uptake in pancreatic tissue or small bowel mucosa was observed between the groups at either two or six weeks (data not shown).

\section{CCK AND GASTRIN CONCENTRATIONS}

After both two and six weeks of duodenogastric reflux, plasma CCK and gastrin con-

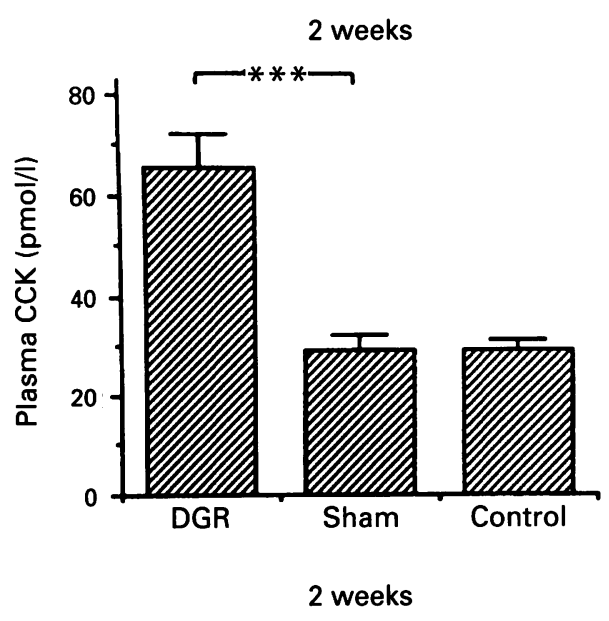

Figure 3: Plasma cholecystokinin (CCK, upper panel) and plasma gastrin (lower panel) in rats two weeks (left) and six weeks (right) after split gastrojejunostomy (DGR). Sham operation (Sham) implies small bowel transection. Control= unoperated controls. $M K=$ devazepide, $25 \mathrm{nmol} / \mathrm{kg} / \mathrm{h} .{ }^{\star}=p<0.05$, $\star \star=p<0.01$, $\star \star \star=p<0.001$.

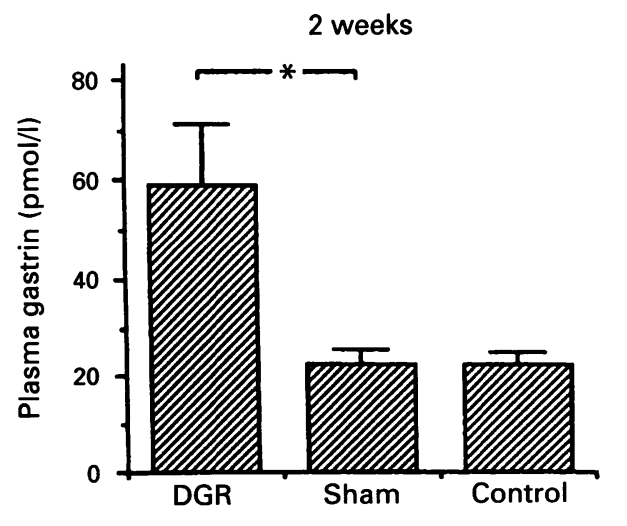

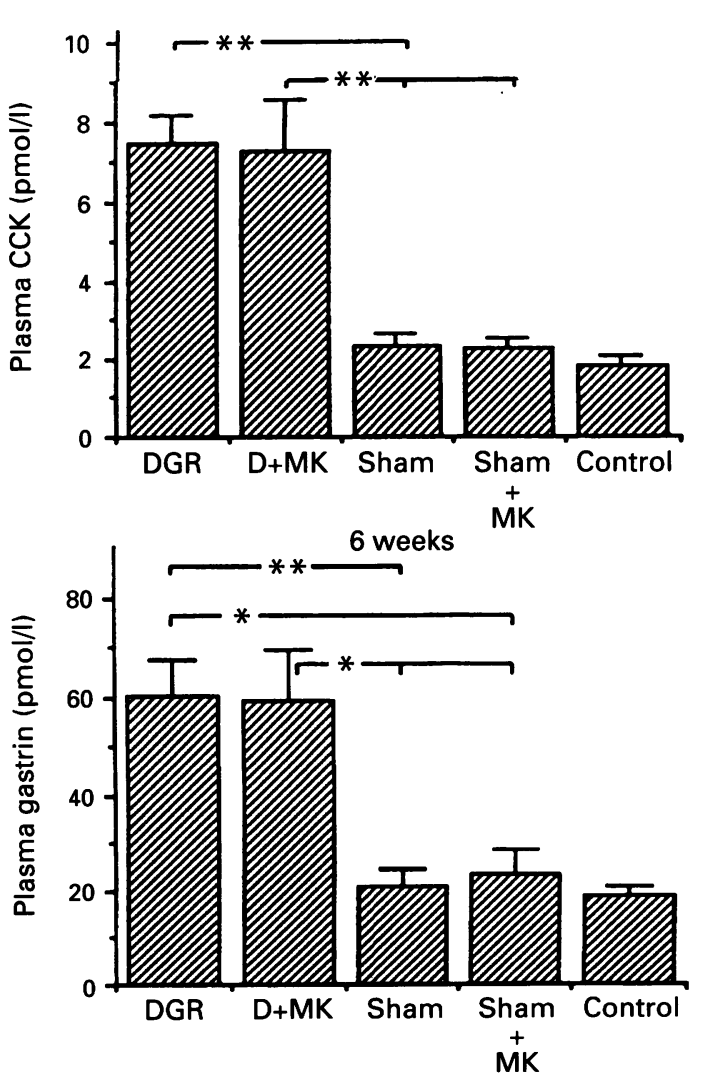


Figure 4: Cholecystokinin (CCK) in duodenal and jejunal mucosa in rats two weeks after split gastrojejunostomy (DGR). Sham operation (Sham) implies small bowel transection.

Control $=$ unoperated controls. ${ }^{\star}=p<0.05$

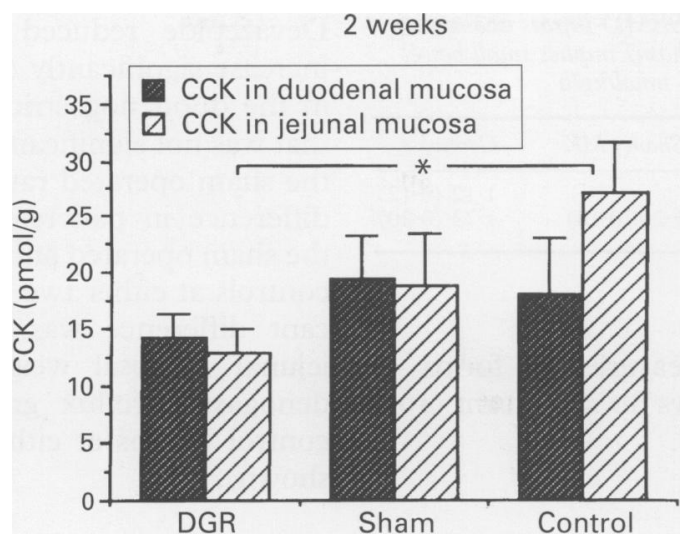

centrations were increased approximately threefold (Fig 3). Devazepide did not affect the plasma levels of either of these peptides. The CCK content in the jejunal mucosa was significantly decreased after two weeks in the duodenogastric reflux group compared with controls (Fig 4), but there was no significant difference at six weeks (data not shown). CCK in the duodenal mucosa was not changed by the procedure at any time point studied.

\section{Discussion}

Duodenogastric reflux is a normal physiological phenomenon ${ }^{25}$ which can become excessive, particularly after gastric surgery in which normal pyloric function is lost. Excessive duodenogastric reflux can give rise to a clinical syndrome with upper abdominal discomfort. ${ }^{25} 26$ It has been implicated as a major factor in the pathogenesis of a variety of benign and malignant foregut diseases, especially in the oesophagus and the stomach. ${ }^{27-30}$ Long term profound duodenogastric reflux in rats, induced by a split gastrojejunostomy, has been shown to result in adenomatous nodules in the pancreas. ${ }^{16}$ The authors found increased CCK and gastrin concentrations associated with the split gastrojejunostomy after four weeks. ${ }^{31}$ As epidemiological studies in man have suggested previous gastric surgery, especially Billroth II gastrojejunostomy, as a risk factor for pancreatic cancer, ${ }^{17-19}$ further study of the mechanisms by which gastric surgery, and associated duodenogastric reflux, may induce pancreatic hyperplasia is of interest.

Pancreatic growth has been seen with bowel resection in rats ${ }^{3}$ and with cholecystectomy in hamsters. ${ }^{4}$ CCK has been suggested as the main growth factor responsible but the mechanism by which CCK is increased is not established. A tenfold increase in the plasma CCK concentration in rats is seen after pancreaticobiliary diversion from the upper small intestine. $^{7-9}$ The release of CCK is normally inhibited by increasing amounts of the pancreatic enzyme trypsin in the upper small intestine ${ }^{32-35}$ but after pancreaticobiliary diversion, with the proximal small intestine void of trypsin, the feedback mechanism is compromised. Pancreaticobiliary diversion induces pancreatic hyperplasia ${ }^{7-9}$ and, in long term studies, causes pancreatic tumours even in the absence of carcinogens. ${ }^{36}$ We have previously shown that CCK is the major growth promoting factor in that experimental model. ${ }^{8}$

The split gastrojejunostomy used in the present study is a surgical model creating a condition not very different from that seen in humans following gastrojejunal anastomosis. Split gastrojejunostomy produces obligatory duodenogastric reflux and is, thus, a suitable model for studies of different effects of duodenogastric reflux. The procedure is well tolerated by the rats, as shown by a weight increase in parallel with sham operated rats and unoperated controls. We found no dilatation of the upper gastrointestinal tract and no macroscopic signs of growth of the small intestine as reported by Taylor et al. ${ }^{16}$ Their finding could be either a long term effect not seen within the first six weeks or due to differences in the surgical techniques used. In our study, duodenogastric reflux induced pancreatic growth, mainly hyperplasia, and a threefold increase in plasma CCK concentrations. The increased pancreatic DNA synthesis, however, must occur within the first two weeks since the ${ }^{3} \mathrm{H}$-thymidine uptake was unchanged at both time points, despite an increase in DNA content. This is similar to our experience with the pancreaticobiliary diversion model. ${ }^{37}$

In a previous study, it was suggested that the source of increased plasma CCK was the hyperplastic duodenum and that the main mechanism was stasis of food within the duodenal loop. ${ }^{1631}$ In the short term, however, we did not see duodenal hyperplasia. Furthermore, the decreased CCK content in the jejunal mucosa at two weeks (and a similar but not significant tendency found after six weeks), together with the unchanged duodenal mucosal weight and mucosal CCK content caused by the split gastrojejunostomy in our study, suggests an increased turnover of the peptide in the efferent jejunal loop. A possible explanation for this effect of reflux on CCK is an inactivation of trypsin when passing through the acid milieu in the stomach and, thus, inhibition of the CCK releasing feedback mechanism in the efferent jejunal loop. Furthermore, it is known that gastric surgery, with bypass of the pylorus, usually induces rapid gastric emptying. Since CCK slows gastric emptying and intestinal transit, ${ }^{38}$ the increased plasma CCK could represent an adaptive response. Studies in humans with previous gastric surgery have shown increased postprandial levels of $\mathrm{CCK},{ }^{39} 40$ and we have found increased CCK concentrations postprandially in patients with primary duodenogastric reflux. ${ }^{41}$

As the CCK receptor antagonist did not completely abolish the pancreatic growth response to the procedure, it is probable that some other factor (or factors) in addition to CCK are involved. This could also reflect an inadequate dose of devazepide but the dose used was the same as has previously been shown to antagonise effects on the pancreas of supra-physiological doses of exogenous CCK. ${ }^{2142}$ A similar dose of devazepide was also able to reduce the effect on pancreatic growth by pancreaticobiliary diversion but not 
significantly affect the size of the normal pancreas. ${ }^{9}$ In the present study, we also found significantly increased plasma gastrin concentrations in the duodenogastric reflux rats, an increase which could be expected after alkalinisation of the stomach. This is in agreement with Taylor's observations. ${ }^{31}$ The effect of gastrin on pancreatic growth is controversial. ${ }^{243}$ In some studies, however, it has been shown to have a weak trophic effect on the pancreas. ${ }^{244}$ It is thus possible that gastrin, in combination with an increase in CCK concentration, could contribute to the growth effects observed in this model.

Pronounced duodenogastric reflux in rats results in pancreatic hyperplasia, due at least partly to increased plasma CCK concentrations. The mechanism by which CCK is increased, however, still has to be elucidated. CCK does not seem to be the sole responsible growth factor in this experimental model. Among other possible candidates is gastrin, which, in some animal studies, has been shown to have trophic effects on the pancreas. ${ }^{24}$ The trophic mechanism is of importance as it may contribute to the increased incidence of pancreatic cancer reported after gastric surgery.

MK329 was kindly donated by V J Lotti, MSD Research Laboratories, West Point, Pennsylvania. Support for this study was provided by NIH Grants no DK40381 and CA44799.

1 Lebenthal E, Leung Y. Fetal and neonatal development of the exocrine pancreas. In: Morriset J, Solomon TE, eds. Growth of the gastrointestinal tract: gastrointestinal hormones and growth factors. Boston: CRC Press, 1990; 73-88.

2 Johnson LR. Trophic effects of gut peptides. In Rauner BB ed. Handbook of physiology (the gastrointestinal system). Bethesda, MA: American Physiological Society, 1989: 291-310.

3 Büchler M, Malfertheiner P, Freiss H, Eiberle E, Begler HG. Gut peptide-mediated adaptive response of the
exocrine pancreas. Scand $\mathcal{f}$ Gastroenterol $1988 ; 23$ (suppl exocrine pancrea

4 Rosenberg L, Duguid WP, Fried GM. Association of cholecystectomy with pancreatic growth and increased plasma levels of cholecystokinin in the syrian golden hamster. f Surg Res 1988; 44: 235-41.

5 Miazza BM, Turberg Y, Guillaume P, Hahne W, Chayvialle JA, Loizeau E. Mechanism of pancreatic growth induced by pancreatico-biliary diversion in the rat. Inhibition by proglumide, benzotript and ranitidine. Scand $f$ Groglumide, benzotript and ranterol 1985; 20 (suppl 112): 75-83.

6 Lee PC, Newman BM, Praissman M, Cooney DR, Lebenthal E. Cholecystokinin: a factor responsible for the enteral feedback control of pancreatic hypertrophy. enteral feedback contro

7 Axelsson J, Håkansson R, Ihse I, Lilja I, Rehfeld JF, Sundler F. Effects of endogenous and exogenous cholecystokinin and of infusion with the cholecystokinin antagonis L364,718 on pancreatic and gastrointestinal growth. Scand F Gastroenterol 1990; 25: 471-80.

8 Gasslander T, Axelsson J, Håkansson R, Ihse I, Lilja I, Rehfeld JF. Cholecystokinin is responsible for growth of the pancreas after pancreaticobiliary diversion in rats. Scand $\mathcal{F}$ Gastroenterol 1990; 25: 1060-5.

9 Nylander A-G, Chen D, Ihse I, Rehfeld JF, Håkansson R. Pancreatic atrophy in rats produced by the cholecysPancreatic atrophy in rats produced by the cholecys-
tokinin-A receptor antagonist Devazepide. Scand $f$ tokinin-A receptor antagon

10 Longnecker DS, Jamieson JD, Asch HL. Regulation of growth and differentiation in pancreatic cancer (conference report). Pancreas 1989; 4: 256-75.

11 Frazier ML, Pathak S, Wang Z-W, Cleary K, Singletary SE, Olive M, Mackay B, et al. Establishment of a new human pancreatic adenocarcinoma cell line, MDAPanc-3. Pancreas 1990; 5: 8-16.

12 Townsend CM Jr, Singh P, Thompson JC. Gastrointestina hormones and gastrointestinal and pancreatic carcinomas. Gastroenterology 1986; 91: 1002-6.

13 Lamers CBHW, Douglas BR, Jansen JBMJ. Cholecystokinin and pancreatic cancer. Scand $\tilde{f}$ Gastroenterol 1988; 23 (suppl 154): 103-6.

14 Liehr R-M, Melnykovych G, Solomon TE. Growth effects of regulatory peptides on human pancreatic cancer lines PANC-1

15 Heald EB, Kramer ST, Smith JP. Trophic effects of unsulfated cholecystokinin on mouse pancreas and human sulfated cholecystokinin on mouse pancreas
pancreatic cancer. Pancreas 1992; 7: 530-5.
16 Tayor PR, Dowling RH, Palmer TJ, Hanley DC, Murphy GM, Mason RC, McColl I. Induction of pancreatic tumours by longterm duodenogastric reflux. Gut 1989; 30: $1596-600$

17 Mack TM, Yu MC, Hanisch R, Henderson BE. Pancreas cancer and smoking, beverage consumption and past medical history. F Natl Cancer Inst 1986; 76: 49-60.

18 Caygill CPJ, Hill MJ, Hall CN, Kirkham JS, Northfield TC. Increased risk for cancer at multiple sites after gastric surgery for peptic ulcer. Gut 1987; 28: 924-8.

19 Caygill CPJ, Hill MJ. Malignancy following surgery for benign peptic disease: a review. Italian fournal of Gastroenterology 1992; 24: 218-24.

20 Chang RSL, Lotti VJ. Biochemical and pharmacological characterization of an extremely potent and selective nonpeptide cholecystokinin antagonist. Proc Natl Acad Sci USA 1986; 83: 4923-6.

21 Zucker KA, Adrian TE, Bilchik AJ, Modlin IM. Effects of the CCK receptor antagonist L364,718 on pancreatic growth in adult and developing animals. Am $\mathcal{f}$ Physiol 1989; 257: G511-6.

22 Labarca C, Paigen K. A simple, rapid and sensitive DNA assay procedure. Anal Biochem 1980; 102: 344-52.

23 Joekel CS, Herrington MK, Vanderhoff JA, Adrian TE. Postnatal development of circulating cholecystokinin and secretin, pancreatic growth, and exocrine function in secretin, pancreatic growth, and exocrine

24 Bryant MG, Adrian TE. Gastrin. In: Bloom SR, Long RG, eds. Radioimmunoassay of gut regulatory peptides. Philadelphia: Saunders, 1982: 51-9.

25 Schindlbeck NE, Heinrich C, Stellaard F, Paumgartner G, Muller-Lissner SA. Healthy controls have as much bile reflux as gastric ulcer patients. Gut 1987; 28: 1577-83.

26 Ritchie WP. Alkaline reflux gastritis. An objective assessment of its diagnosis and treatment. Ann Surg 1980; 192: 288-98.

27 Mason RC. Duodenogastric reflux in rat gastric carcinoma. Br F Surg 1986; 73: 801-3.

28 Taylor PR, Mason RC, Filipe MI, Vaja S, Hanley DC, Murphy GM, et al. Gastric carcinogenesis in the rat induced by duodenogastric reflux without carcinogens: morphology, mucin histochemistry, polyamine gens: morphology, mucin histochemistry, polyamine metabolism

29 Lin KM, Ueda RK, Hinder RA, Stein HJ, DeMeester TR. Etiology and importance of alkaline esophageal reflux. Am $\mathcal{F}$ Surg 1991; 162: 553-7.

30 Seto Y, Kobori O, Shimizu T, Morioka Y. The role of alkaline reflux in esophageal carcinogenesis induced by $\mathrm{N}$-amyl-N-methylnitrosamine in rats. Int $\mathcal{f}$ Cancer 1991 ; 49: 758-63.

31 Taylor PR, Houghton A, Mason RC. Trophic gut hormones and pancreatic tumour formation in the rat. hormones and pancreatic tur

32 Ihse I, Lilja P, Lundquist I. Trypsin as a regulator of pancreatic secretion in the rat. Scand $\mathcal{F}$ Gastroenterol 1979; 14: 873-80.

33 Louie DS, May D, Miller P, Owyang C. Cholecystokinin mediates feedback regulation of pancreatic enzyme secretion in rats. Am F Physiol 1986; 250: G252-9.

34 Owyang C, Louie DS, Tatum D. Feedback regulation of pancreatic enzyme secretion. Suppression of cholecystokinin release by trypsin. F Clin Invest 1986; 77: 2042-7.

35 Fölsch UR, Cantor P, Wilms HM, Schaftmayer A, Becker HD, Creutzfeldt W. Role of cholecystokinin in the negative feedback control of pancreatic enzyme secretion in conscious rats. Gastroenterology 1987; 92: 449-58.

36 Stace NH, Palmer TJ, Vaja S, Dowling RH. Longterm pancreaticobiliary diversion stimulates hyperplastic and adenomatous nodules in the rat pancreas: a new model for spontaneous tumour formation. Gut 1987; 28 (S1): $265-8$.

37 Gasslander T, Chu M, Smeds S, Ihse I. Proliferative response of different exocrine pancreatic cells after surgical pancreaticobiliary diversion in the rat. Scand $\mathcal{F}$ Gastroenterol 1991; 26: 399-404.

38 Rehfeld JF. Cholecystokinin. In: Rauner BB, ed. Handbook of physiology. The gastrointestinal system. Bethesda, MA: American Physiological Society, 1989: 337-58.

39 Hopman WPM, Jansen JBM, Lamers CBHW. Plasma cholecystokinin response to oral fat in patients with 199: 276-80.

40 Mössner J, Regner UF, Zeeh JM, Bruch H-P, Eberlein G. Influence of food on plasma cholecystokinin and gastrin in patients with partial gastric rections and Roux-en-Y anastomoses. $Z$ Gastroenterol (Verb) 1989; 27: 94-8

41 Wilson P, Welch NT, Hinder RA, Anselmino M, DeMeester TR, Adrian TE. Abnormal plasma gut hormones in pathologic duodenogastric reflux and their response to surgery. Am f Surg 1993 165: 169-77.

42 Modlin IM, Bilchik AJ, Zucker KA, Adrian TE, Sussman J, Graham SM. Cholecystokinin augmentation of 'surgical' pancreatitis. Benefits of receptor blockade. Arch Surg 1989; 124: 574-8.

43 Håkansson R, Blom H, Carlsson E, Larsson H, Ryberg B, Sundler F. Hypergastrinemia produces trophic effects in stomach but not in pancreas and intestines. Regulatory Peptides 1986; 13: 225-33.

44 Solomon TE, Morriset J, Wood JG, Bussjaeger JL. Additive interaction on pentagastrin and secretin on pancreatic interaction on pentagastrin and secretin on pa
growth in rats. Gastroenterology 1987; 92: 429-35. 